Tyndale Bulletin 69.2 (2018) 183-203

\title{
MORAL TRANSFORMATION THROUGH MIMESIS IN THE JOHANNINE TRADITION
}

Cornelis Bennema ${ }^{1}$

(c.bennema@gmail.com)

\begin{abstract}
Summary
Johannine ethics is a problematic area for scholarship but recently there has been a breakthrough. In this new era of exploring Johannine ethics, the present study examines the concept of moral transformation through mimesis. The argument is that when people live in God's world, their character and conduct are shaped in accordance with the moral beliefs, values, and norms of the divine reality, and that mimesis proves to be instrumental in this process of moral transformation. The study also explores how Johannine Christians in the late first century could imitate an 'absent' Jesus and what they were seeking to imitate.
\end{abstract}

\section{Introduction}

This study in Johannine ethics explores moral transformation through mimesis in John's Gospel and Letters. ${ }^{2}$ I use the term 'moral transformation' to refer to 'the shaping of a person's character and conduct when they understand, embrace, and live out the beliefs, values, and norms of God's world'. While the Johannine writings present various kinds of mimesis, this study focuses on the believerJesus mimesis, where Jesus sets the example for believers to imitate so

1 Cornelis Bennema is Extraordinary Associate Professor at the Unit for Reformed Theology and the Development of the South African Society, Faculty of Theology, North-West University, South Africa.

2 The use of 'John' for the author(s) of the Johannine writings is not a claim to a particular historical identity. The similarities in language, syntax, style, and thought between the Gospel and Letters warrant an examination of both writings. References to chapter and verse only come from John's Gospel. 
that they may (gradually) become like him. ${ }^{3}$ However, it is legitimate to speak of moral transformation and mimesis, only if we can treat the Johannine writings as ethical texts. After all, John does not address moral issues such as divorce, purity laws, or sexual immorality. Strictly speaking, there is no ethics in John because there is no system of moral codes like the Sermon on the Mount or a systematic reflection on morality like Aristotle's Nicomachean Ethics. John seems to promote only one ethic - to love one another - and even this raises many questions. So, it is unsurprising that most scholars have ignored John when it comes to ethics. Recently, however, two volumes of essays have provided scholarship with a new impetus to explore Johannine ethics. ${ }^{4}$ Nevertheless, neither volume contains an essay on moral transformation or mimesis. Other publications on Johannine ethics also have different emphases than our study. ${ }^{5}$ While I have written about moral transformation and mimesis in John separately, this study links

3 The term 'believer' refers to a person who has pledged allegiance to Jesus as his disciple or follower. Besides the believer-Jesus mimesis, John mentions the occasional believer-God mimesis, the paradigmatic Son-Father mimesis, and a latent Spirit-Jesus mimesis. See Cornelis Bennema, Mimesis in the Johannine Literature: A Study in Johannine Ethics (LNTS 498; London: T\&T Clark, 2017).

4 Jan G. van der Watt and Ruben Zimmermann, ed., Rethinking the Ethics of John: 'Implicit Ethics' in the Johannine Writings (WUNT 291; Tübingen: Mohr Siebeck, 2012); Sherri Brown and Christopher W. Skinner, ed., Johannine Ethics: The Moral World of the Gospel and Epistles of John (Minneapolis: Fortress, 2017). Especially the essays by Michael Labahn and Ruben Zimmermann (in the first volume) and Christopher Skinner (in the second volume) provide a legitimate basis for doing Johannine ethics.

5 For example, Mira Stare, 'Der Lebensbegriff als ethische Norm im Johannesevangelium' in Ethische Normen des frühen Christentums: Gut-Leben-LeibTugend, Friedrich W. Horn, Ulrich Volp, and Ruben Zimmermann, ed. (WUNT 313; Tübingen: Mohr Siebeck, 2013): 257-80; Jörg Frey, "Ethical” Traditions, Family Ethos, and Love in the Johannine Literature' in Early Christian Ethics in Interaction with Jewish and Greco-Roman Contexts, Jan Willem van Henten and Joseph Verheyden, ed. (STAR 17; Leiden: Brill, 2013): 167-203; Karl Weyer-Menkhoff, Die Ethik des Johannesevangeliums im sprachlichen Feld des Handelns (WUNT II/359; Tübingen: Mohr Siebeck, 2014); Fredrik Wagener, Figuren as Handlungsmodelle: Simon Petrus, die samaritische Frau, Judas und Thomas als Zugänge zu einer narrative Ethik des Johannesevangeliums (WUNT II/408; Tübingen: Mohr Siebeck, 2015); Lindsey M. Trozzo, Exploring Johannine Ethics: A Rhetorical Approach to Moral Efficacy in the Fourth Gospel Narrative (WUNT II/449; Tübingen: Mohr Siebeck, 2017); Mavis M. Leung, 'Ethics and Imitatio Christi in 1 John: A Jewish Perspective', TynB 69 (2018): 111-31 (she explains imitating Jesus in 1 John in light of the Old Testament idea of imitating God). For an assessment of Dirk van der Merwe's 2001 article on mimesis in John's Gospel and Jan van der Watt's 2016 articles on mimesis in 1 John, see Bennema, Mimesis: 13,16-17. 
these topics more explicitly. ${ }^{6}$ I will argue that when people live in God's world, their character and conduct are shaped by the moral beliefs, values, and norms of God's world (Section 2), and that mimesis is instrumental in this process of moral transformation (Section 3). Unaddressed previously, this study will explore how mimesis may have worked among Johannine believers in the late first century (Section 4).

\section{Moral Transformation}

The Johannine writings present a narrative world where two mutually exclusive moral realms and rulers are pitted against each other. Immoral categories such as darkness, hate, lies, sin, and murder are related to the devil and his realm (including its people). Moral attributes or qualities such as life, light, love, truth, good, righteous, pure, and holy are ascribed to God and Jesus and those who belong to him. For John, the ultimate moral attainment for people is to participate in the life of God and Jesus $\left(20: 31 ; 1\right.$ John 5:13). ${ }^{7}$ A person's moral transformation starts with a new birth of the Spirit, a relocation from the dark, immoral world to the moral world of God. This new birth involves a new identity - one becomes a child of God, part of his family - and this new identity should lead to new behaviour. ${ }^{8}$ Believers must now think and live in line with this new environment and their

6 I only hinted at mimesis in Cornelis Bennema, 'Moral Transformation in the Johannine Writings', In die Skriflig 51.3 (2017): 1-7, here 6 (see also idem, 'Virtue Ethics and the Johannine Writings', in Brown and Skinner, ed., Johannine Ethics: 26181, here 276-77), while in my monograph, I touched on moral transformation in a chapter that seeks to situate mimesis in the broader field of Johannine ethics (Bennema, Mimesis: 143-69).

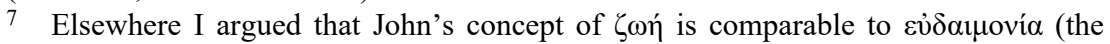
supreme good or moral goal) in Graeco-Roman virtue ethics (Bennema, "Virtue

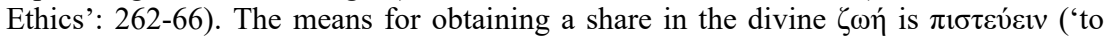
believe') in Jesus (20:31; 1 John 5:13), which is a moral act according to 6:27-29.

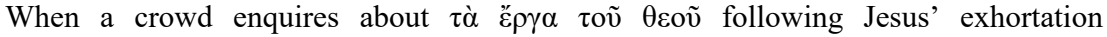

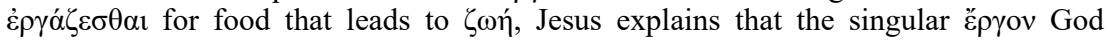
requires from them is $\pi 1 \sigma \tau \varepsilon v \varepsilon \varepsilon v$ in Jesus. Hence, belief in Jesus is the proper moral response that people should render to God; conversely, unbelief is immoral or sin (16:9).

8 'Family' (John uses the terms oĩkoৎ and oíkía) is a major theological category in John. Just as 'family' denotes the basic social unit in ancient cultures, so the 'family of God' describes the basic unit of the divine society. The nucleus of the divine family comprises God the Father and Jesus the Son, and people can enter God's family through a birth of the Spirit (1:12-13; 3:5). 
moral transformation will correspond to the extent that they are able to think and behave according to the divine reality.

\subsection{Sharing In and Living Out the Divine Moral Attributes}

When people enter God's family and participate in the relationship that the Father and Son share, the moral qualities that define God begin to shape their identity and behaviour. I will mention the most prominent qualities.

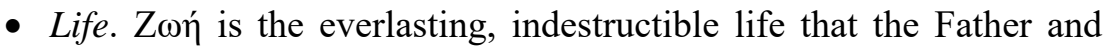
Son share and what defines them $(1: 4 ; 5: 26 ; 14: 6)$. Life is a moral quality because it represents the continual existence of a moral God and because he invites people to share in his life. As believers partake in the shared life of the Father and Son, they themselves become a derivative source of life for others $(7: 38) .{ }^{9}$

- Love. Love defines God and Jesus $(3: 35 ; 14: 31 ; 1$ John $4: 8,16)$, and this shared love is extended to people $(14: 21,23 ; 16: 27)$. God showed his love for people by giving up his Son at the cross as an atoning sacrifice (i入 $\alpha \sigma \mu$ ós) for humanity's sins $(3: 16 ; 1$ John 4:810). Love drives Jesus to give his life for the life of the world (1 John $3: 16)$. Hence, love is a moral category because it drives God to act morally on behalf of immoral people. Love identifies those who belong to God's family and this love should be discernible in the believers' behaviour (13:34-35; 1 John 3:16-18).

- Light. Jesus is described as the life-giving light of the world (1:4-5; $8: 12 ; 12: 46)$ and God is also described as light (1 John 1:5). Light is a moral quality of the Father and Son because it is associated with $\zeta \omega \eta$ and contrasted with the immoral darkness that characterises the world $(1: 4-5,9) .{ }^{10}$ This moral light is made available to people when

9 While the majority of scholars favour a 'Christological' interpretation of 7:37-38

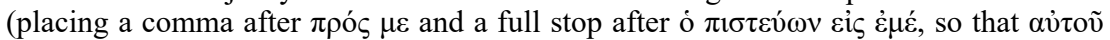
refers to Jesus), I contend that a full stop should be placed after $\pi$ ivé $\tau \omega$, in which case

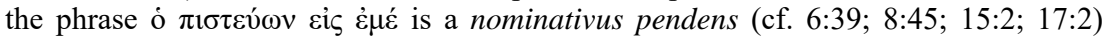

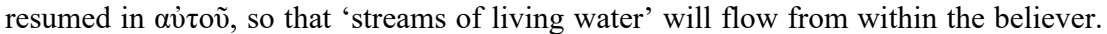
Hence, in addition to Jesus being the primary source of life-giving water, believers become derivative sources of life-giving water. The best case for this position remains the one made by Juan B. Cortés, 'Yet Another Look at John 7,37-38', CBQ 29 (1967): 75-86.

10 The darkness that characterises the world and its people is inter alia a moral darkness because the dark world rejects the life-giving Light (1:4-11). People engage in morally dubious behaviour ( $\pi \rho \alpha \dot{\tau} \tau \varepsilon \mathrm{v} v \varphi \alpha \tilde{\lambda} \lambda \alpha$ ) and have immoral inclinations - they

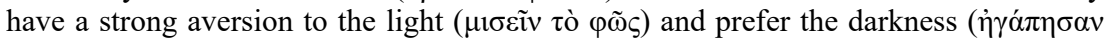


the Logos-Light enlightens people and dispels their immoral darkness $(1: 9 ; 12: 46 ; 1$ John $2: 8)$. People are called 'children of light' when they accept the Light (12:35-36) and their behaviour should reflect this moral light $(3: 19-21 ; 11: 9-10 ; 1$ John $1: 7 ; 2: 10)$.

- Truth. 'Truth' is Johannine shorthand for the divine reality about God and his world, which Jesus reveals and mediates to people $(1: 14-18 ; 3: 31-33 ; 8: 40,45 ; 14: 6)$. Truth is the defining moral component of Jesus' teaching because it liberates people from sin and provides moral cleansing $(8: 31-32 ; 15: 3 ; 17: 17)$. People who accept Jesus' liberating truth then become from 'from the truth' (18:37; 1 John 3:19). John uses various expressions to show that this truth will shape their behaviour: 'to do the truth' (3:21), 'to testify to the truth' (15:27), 'to worship in truth' (4:23-24), 'to be guided into the truth' (16:13), 'to love in truth' (1 John 3:18; 5:20).

In short, the moral attributes that characterise the Father and Son and direct their actions also shape the character and conduct of believers. I will now show that believers can only live out these moral qualities to the extent that these have shaped their thinking and behaviour.

\subsection{Moral Reasoning}

Believers or members of God's family are expected to align their thinking to their new environment, the world above, and this new thinking should inform their behaviour. Moral reasoning or thinking 'from above' is to think in line with God's character and purposes, to reason according to the beliefs, values, and norms of the world above. Typically, characters in the Johannine narrative show a thinking 'from below'. This is unsurprising considering people are 'from below' $(8: 23,43-47)$. On various occasions, Jesus starts a conversation at an earthly level, but quickly moves to a spiritual level and people are often unable to follow. Typical examples are Nicodemus (3:2-12), the crowd (6:25-34; 7:25-30; 12:37-40), 'the Jews' (6:41-59; 8:39-59; 9:39-41), Pilate (18:36-38; 19:9-11), but also the Twelve (4:31-34), Philip (6:5$7)$, and Peter (13:36-38; 18:10-11). Some characters, however, do begin to think 'from above', although they struggle and often require Jesus' help, such as the Samaritan woman (4:10-26), the man born

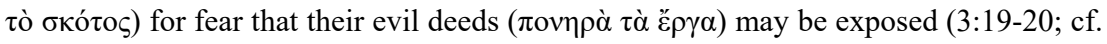
$7: 7)$. 
blind (9:17-38), Martha (11:21-27), and Mary Magdalene (21:14-18), and they function as models of moral reasoning.

So, moral reasoning corresponds to the extent to which a person understands Jesus' teaching about God's world. But this is not easy. The teaching of the Johannine Jesus is enigmatic or ambiguous because it contains metaphors, symbolism, and irony, which are open to misunderstanding. In 16:25, Jesus refers to his teaching as being 'veiled' ( $\pi \alpha \rho o \mu$ í $\alpha$ ), but promises to speak 'plainly' ( $\pi \alpha \rho \rho \eta \sigma i \alpha)$ in the future. This refers to the time of the Spirit. According to 14:26 and 16:12-15, the Spirit will explain everything that Jesus has said in such a way that Jesus' words become plain. John records a few instances where the disciples are able to grasp Jesus' teaching after the resurrection $(2: 17,22 ; 12: 26 ; 16: 4)$. This thinking 'from above' is most likely the result of the Spirit's anamnesis (14:26). Indeed, in his first letter John describes the post-Easter reality where believers are able to think 'from above' because of the Spirit (1 John 2:27). The extent to which John and his fellow believers can think 'from above' is indicated by the frequent phrase '(by this) we/you know that' (1 John 2:5,18,21; $3: 5,14-16,19,24 ; 4: 2,6,13 ; 5: 2,15,18-20)$. So, in the post-Easter era, the cognitive darkness that tarnishes the world and its people $(1: 5,9-11)$ is dissipating (1 John 2:8).

In sum, Jesus taught in 'veiled' language and was often misunderstood because people failed to think 'from above', a prerequisite for gaining spiritual insight into the things of God. In the post-Easter period, the Spirit functions as a decoder, decrypting or unlocking Jesus' revelation, thereby enabling a thinking 'from above'. Moral reasoning or thinking 'from above' facilitates moral transformation because it informs and shapes both thought and behaviour according to the values and norms of the world above. Moral reasoning undergirds moral behaviour because the number of explicit moral instructions in the Johannine writings is not exhaustive; rather, believers must learn to think morally, and this moral reasoning should direct their behaviour. ${ }^{11}$ This moral shaping of character and conduct is the topic of the next section.

11 Nico J. Grönum also argues that fostering moral deliberation is important for behavioural change, otherwise people only operate by instinctive behaviour guided by cultural schemata ('A Return to Virtue Ethics: Virtue Ethics, Cognitive Science and Character Education', Verbum et Ecclesia 36.1 [2015]: 1-6, http://dx.doi.org/10.4102/ ve.v36i1.1413). 


\subsection{Moral Behaviour and Identity}

Becoming part of God's family does not only result in a new identity but also a new mode of conduct. Believers are expected to behave in line with the ethos of God's world. This developing moral behaviour is usually referred to as 'discipleship'. Consequently, we find various ethical imperatives in the Johannine writings to direct the believer's behaviour, such as to love one another, to abide in Jesus and his word, to bear fruit, to keep his commandments, to serve one another, to lay down one's life for others, to testify about Jesus, and to 'do' the truth. In fact, the Johannine writings stress the correlation between identity and behaviour, which means that moral transformation is not just about behaviour but also relates to identity.

John 8:39-47 provides a good example of the dynamics of identity and behaviour and brings into sharp focus two mutually exclusive families. When 'the Jews' claim that Abraham is their father (an issue of identity), Jesus says that if this were the case they would demonstrate corresponding behaviour. In other words, identity demands matching behaviour and, conversely, behaviour reveals identity. As it is, the behaviour of 'the Jews' demonstrates that they do not belong to God's family but to the family of the devil. This link between identity and behaviour is also found elsewhere in John's Gospel. To his disciples, Jesus stresses that keeping his commandments shows their love for him $(14: 15,21,23)$ and guarantees his abiding love (15:10). Similarly, their loving one another is a testimony to their identity as Jesus' disciples (13:35). In the parable of the vine and its branches, Jesus asserts that abiding in him, that is being in relationship with him (identity), warrants that they bear fruit (behaviour) (15:4-5), and in turn their bearing fruit will reveal identity (15:8).

$1 \mathrm{John}$ is also replete with examples of this correlation between identity and behaviour: (i) anyone claiming to have communion with God (identity) must show matching behaviour; conversely, one who 'walks' in the light or darkness (behaviour) is in the light or darkness (identity) (1 John 1:6-7; 2:9-11); (ii) keeping God's commandments (obedient behaviour) affirms one's communion with God (one knows God and is 'in him') and one's share in the divine attributes of truth and love (identity) (1 John 2:3-6); (iii) identity and behaviour are inseparable in either family - to do right (not to commit sin) is to be right, to be of God; to commit sin is to be of the devil (1 John 3:7-10); 
(iv) when God's love abides in the believer (identity), it must result in corresponding behaviour (1 John 3:17), just as to 'love in truth' (behaviour) demonstrates that one is of the truth (identity) (1 John 3:18-19); (v) to love (behaviour) is to be (born) of God who is love, and guarantees one's communion with him (identity) (1 John 4:7-8,12); (vi) to testify (behaviour) shows communion with God (identity) (1 John 4:15); (vii) love (identity) is inextricably linked with, even defined by, obedience (behaviour) (1 John 5:2-3).

A picture emerges that the believers' inclusion in the divine identity must precipitate transformational behaviour in that they are expected to behave according to the divine family code. Believers should behave like children of God because that is who they are (see also 1 John 3:1). The believer's ongoing access to the divine reality results in a growing awareness of who God is, what he does, and what he expects from people. This moral knowledge should motivate a believer to do what is right. At the same time, behaviour is transformative - right behaviour affirms and shapes one's identity. Continuous acts of discipleship (behaviour), such as believing, loving, following, abiding, obedience, serving, and testifying, authenticate and shape the family bond between the believer, God, and fellow-believers (identity). In short, there is a reciprocal, transformative dynamic between identity and behaviour; each has the potential to shape the other.

\section{Transformation through Mimesis}

In Graeco-Roman and Jewish antiquity, mimesis in relation to people occurred mainly in the spheres of family and education where children were expected to imitate their parents and pupils their teachers in order to become like their role models. ${ }^{12}$ The use of personal example is crucial in the mimetic process of learning. As first-century Roman rhetorician Quintilian puts it,

We must not read or listen to orators merely for the sake of acquiring words. For in everything which we teach examples are more effective even than the rules which are taught in the schools, so long as the

12 Willis Peter de Boer, The Imitation of Paul: An Exegetical Study (Kampen: Kok, 1962): 6-15; David B. Capes, 'Imitatio Christi and the Gospel Genre', BBR 13 (2003): 1-19, here 3-10; Victor A. Copan, Saint Paul as Spiritual Director: An Analysis of the Imitation of Paul with Implications and Applications to the Practice of Spiritual Direction (Colorado Springs, CO: Paternoster, 2007): 46-63. 
student has reached a stage when he can appreciate such examples without the assistance of a teacher, and can rely on his own powers to imitate them. And the reason is this, that the professor of rhetoric lays down rules, while the orator gives a practical demonstration. (Institutio Oratoria 10:1:15; LCL 124)

We see this confirmed in John. Jesus often sets the example of moral behaviour for his disciples to imitate. The episode that illustrates this best is the footwashing in John 13 where Jesus exhorts his disciples to imitate him in serving one another in loving humility: 'For I gave you

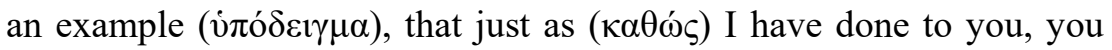

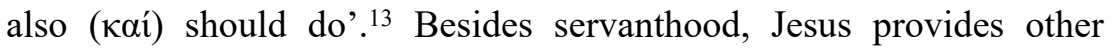
examples of moral behaviour for his disciples to imitate. When Jesus issues the well-known love command in 13:34a, verse $34 \mathrm{~b}$ expands verse $34 \mathrm{a}$ with a mimetic imperative: 'Just as I have loved you, you also should love one another.' The significance is that the love command is not given in a vacuum but is derived from a precedent. In other words, the disciples' love for one another is based on their personal experience of Jesus' love for them - they have, for example, experienced this in the footwashing (cf. 13:1). Echoing the language of 13:15, we could say that Jesus' love for his disciples is the $v \pi$ ó $\delta \varepsilon 1 \gamma \mu \alpha$ for their love for one another. This mimetic construction, 'just as Jesus did, his followers also should do', occurs more often in John (15:10; $17: 18 ; 20: 21)$. In addition, John mentions other instances of the believer-Jesus mimesis, such as to be where Jesus is (12:26; 14:3; 17:24), to be united with Jesus (and God) (17:11,21-22), to behave like Jesus (1 John 2:6), to be like Jesus (1 John 3:2), to be right(eous) like Jesus (1 John 3:7), and to lay down one's life like Jesus did (1 John $3: 16) .{ }^{14}$

We noted earlier that the goal of mimesis is moral transformation in that the imitator seeks to become (gradually) like the exemplar. Believers imitate Jesus in sacrificial service, loving one another, and so

13 Understanding Jesus' example in terms of loving service does, of course, not exhaust its meaning. See, for example, R. Alan Culpepper, 'The Johannine hypodeigma: A Reading of John 13', Semeia 53 (1991): 133-52 (to imitate Jesus' virtuous death); Mary L. Coloe, 'Welcome into the Household of God: The Foot Washing in John 13,' CBQ 66 (2004): 400-415 (to welcome believers into God's family).

14 In fact, John's mimetic language is both varied and widespread in that he uses eight different linguistic construction to create approximately forty-four occurrences of mimesis, with twenty-three referring to the believer-Jesus mimesis (Bennema, Mimesis: 39-63). 
on, so that they become people characterised by love and service. A pattern of transformation through mimesis emerges where Jesus shows an example of moral behaviour and his disciples can then (and therefore) imitate him. I will now explain mimesis with reference to the same three categories I used for moral transformation in Section 2.

\subsection{Mimesis and the Divine Attributes}

We saw earlier that the relationship between the Father and Son, in which believers share, is characterised by the moral qualities of life, light, love, and truth. In this section, I will suggest that believers can share in these divine attributes because they are extended to them through mimesis, shaping both their identity and behaviour. We can detect a mimetic chain where the Father sets the example for the Son, and in turn the Son sets the example for his followers. Hence, in imitating the Father, Jesus mediates these moral commodities to people.

- Regarding life, just as the Father has granted the Son to be a source of life in imitation of him $(5: 21,26)$, so believers become an auxiliary source of life in imitation of Jesus. For example, when the Samaritan woman has drunk from the life-giving water that Jesus offered her, she, in turn, becomes a derivative or imitative source of life when her testimony leads her fellow villagers to the source of life (4:28-30,39). Similarly, the disciples' testimony will elicit belief (17:20) precisely because they have become a derivative source of life (7:38-39). Hence, access to life is 'passed on', as it were, via a mimetic chain from the Father to the Son to believers to potential believers.

- As for love, the mimetic chain of love is evident: the Son loves the disciples just as the Father loves him (15:9), so the disciples (should) love one another in imitation of Jesus (13:34; 15:12).

- Truth is the essence of divine speech (8:31-32) and since Jesus imitates the Father's speech $(8: 26,28 ; 12: 50)$ Jesus' teaching is a source of truth for people. Believers, in turn, become a source of truth for others because their testimony, guided by the Spirit of truth, is modelled on Jesus' teaching (15:26-27; 16:12-15; 17:20).

- Although there is no Son-Father mimesis regarding light, there is arguably an implied mimesis in the depiction of John the Baptist. Jesus' description of John as a shining lamp in 5:35 refers to John's activity of testifying to the Light, which elicits belief $(1: 7 ; 1: 35-37$; 
10:41-42). Likewise, believers are called to testify to the Light $(15: 27)$ and their testimony has the potential to provide light $(17: 20)$. Hence, it could be argued that believers 'imitate' Jesus as light.

In sum, the core attributes that characterise the Father-Son relationship are mediated to believers through mimesis. And if these attributes shape the believers' identity and behaviour, we may conclude that mimesis is instrumental for moral transformation. I will now look at the concepts of moral reasoning and the relation between behaviour and character with regard to mimesis.

\subsection{Mimesis and Moral Reasoning}

John's concept of mimesis is not about aping or mindless replication; rather, it is a dynamic and creative hermeneutical process. Revisiting the footwashing, it is revealing that when Jesus returns to the table after washing his disciples' feet he does not simply command his disciples

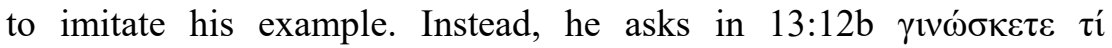
$\pi \varepsilon \pi$ oí $\eta \kappa \alpha$ v $\mu \mathrm{iv}$ ('Have you understood what I have done for you?').

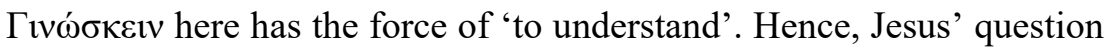
constitutes a cognitive challenge for the disciples, implying that what they have observed needs to be followed by understanding. ${ }^{15}$ They must interpret Jesus' example in order to imitate him. They should

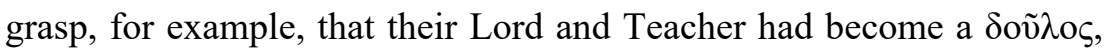
showing that no one is exempt from humble service and that they need to become $\delta$ oṽ $\lambda$ oí too. Jesus' question in 13:12 injects a cognitive aspect into the concept of mimesis and reveals that mimesis has two components: (i) the interpretation of the original act; and (ii) the resulting mimetic act. For John, mimesis is a hermeneutical process where the disciples have to interpret Jesus' example in order to imitate it. Hence, the mimetic act is not limited to a replication of the original, but can be a creative expression of that act. In washing his disciples' feet, Jesus' intention is that the disciples understand the need for humble, loving service to one another and produce a tangible act that creatively but truthfully articulates this understanding. An authentic mimetic act must stay within the conceptual domain of the original act. For example, showing compassion for the homeless by talking to them

15 While the first meaning of the footwashing would become clear to the disciples after Easter (13:7), they are required to understand its second meaning immediately (13:12b-17). 
and giving them a meal falls within the conceptual mimetic domain of the footwashing, but throwing money at them does not.

Other forms of Johannine mimesis also suggest the need for moral discernment. For instance, to be sent into the world by Jesus just as Jesus was sent into the world by the Father $(17: 18 ; 20: 21)$ needs discernment because this looks different for each believer. Moral discernment regarding the 'oneness' and 'indwelling' of the Father and Son (17:11,21-22) should guide how the mimesis of this union is worked out in the corporate life of the believing community. The mimetic actions of believers demonstrating love for one another in different situations needs moral reasoning. In short, authentic mimesis requires moral reasoning in that the intention and attitude behind Jesus' example must be interpreted and articulated truthfully in a corresponding mimetic act.

Moral reasoning may even lead to new forms of mimesis. I say this because John himself does so in his first letter by creating several new mimetic instances.

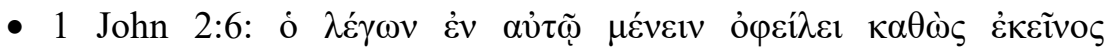

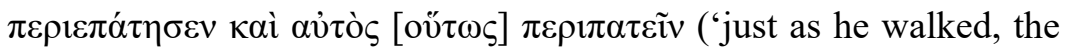
one who claims to abide in him must also walk [similarly]). ${ }^{16}$ $\Pi \varepsilon \rho 1 \pi \alpha \tau \varepsilon i v$ ('to walk') is shorthand for 'way of life', referring to Jesus' life on earth as a model for imitation. ${ }^{17}$ This mimetic imperative is probably derived from Jesus' saying in 14:6 that he is the 'way of life' in which people should walk (taking $\dot{\eta}$ ódós ... kaì $\dot{\eta} \zeta \omega \eta$ as 'the way that is life'). ${ }^{18}$ This general mimesis has three manifestations in the Johannine literature: (i) 'to walk in the light' (11:9-10; 12:35; 1 John 1:6-7), that is to live in the realm of Jesus; (ii) 'to walk in the truth' ( 2 John $4 ; 3$ John 3-4), that is to act in correspondence with the divine reality, which is bound up with Jesus; (iii) 'to walk according to his commandment(s)' (2 John 6), that is to show conduct that is exemplified by love. In short, believers should discern and demonstrate Christ-like behaviour that

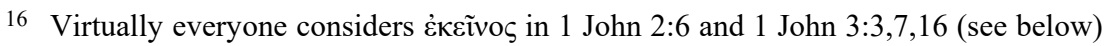
to refer to Jesus.

17 Connecting $\mu \varepsilon \dot{v \varepsilon ı v}$ and $\pi \varepsilon \rho \imath \pi \alpha \varepsilon \varepsilon \tilde{v}$, Hans-Josef Klauck contends that abiding is not something static but a dynamic activity (Der erste Johannesbrief, [EKKNT 23.1; Neukirchen-Vluyn: Neukirchener, 1991]: 118).

18 In addition, Leung sees parallels with 'walking in the way of the Lord' in the OT ('Ethics': 125-26). 
is characterised by the divine moral qualities of light, truth, and love (cf. Section 3.1).

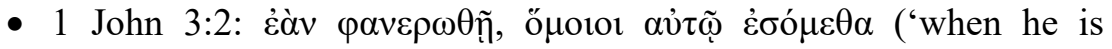

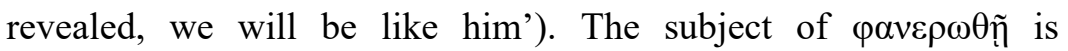
probably Jesus because he often is the subject of the passive form of

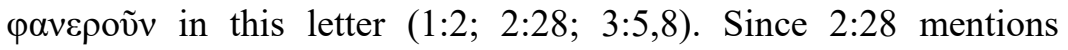
$\pi \alpha \rho o v \sigma i \alpha$, the idea in 3:2 is that at the Parousia, believers will be transformed into the likeness of Christ. The believers' mimetic transformation probably refers to becoming like Jesus in his humanity - to become truly human. ${ }^{19}$

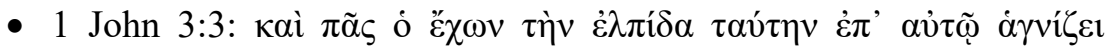

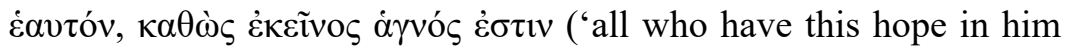
purify themselves, just as he is pure'). This occurrence of mimesis is perhaps rooted in 17:19. Although the mimetic idea seems weak - it does not say that believers must purify themselves just as Jesus purified himself (because Jesus is pure) - it nevertheless urges believers to imitate Jesus and become pure.

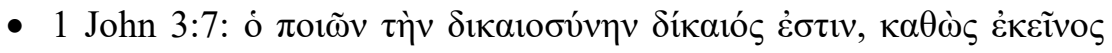

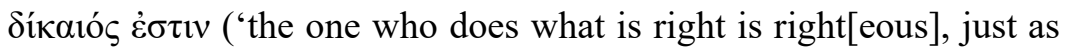
he is right[eous]'). This occurrence of mimesis may be influenced by $5: 30$ and $7: 24$.

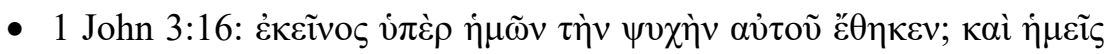

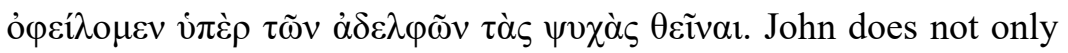
remind his audience of Jesus' saying in 15:13 but turns it into a new mimetic imperative: just as Jesus laid down his life for his followers' sake, so believers should lay down their lives for each other. To get from the mimetic imperative to imitate Jesus' sacrificial love in 1 John 3:16 to the specific mimetic act of giving economic aid to a fellow believer in 1 John 3:17 certainly takes moral reasoning.

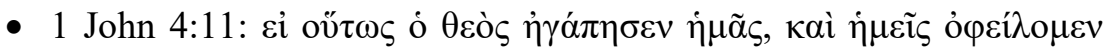
$\dot{\alpha} \lambda \lambda \hat{\eta} \lambda$ ov $\dot{\alpha} \gamma \alpha \pi \tilde{\alpha} v$ ('since God loved us in this manner, we also must

19 If one wants to use the term 'theosis' to describe this transformation, it should be understood in terms of participation in God's life and character in order to become like God rather than participation in God's essence in order to become God. See further Andrew J. Byers, Ecclesiology and Theosis in the Gospel of John, (SNTSMS 166; Cambridge: Cambridge University Press, 2017); Michael Gorman, Abide and Go: Missional Theosis in the Gospel of John (Eugene: Wipf \& Stock, 2018). 
love one another'). This mimetic imperative is a conflation of $3: 16$ and 13:34.

Hence, we have in 1 John several instances of moral reasoning where John imitates Jesus at a meta-level by fashioning new forms of mimetic behaviour from Jesus' teaching and personal example.

\subsection{Mimesis, Moral Behaviour, and Identity}

In Section 2, we saw that when people become part of the divine realm where God rules, the shaping of their identity and behaviour constitutes moral transformation. In this section, I will suggest that mimesis is a crucial mechanism for linking behaviour and identity. Regarding the

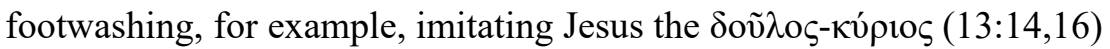
would mean not just performing acts of sacrificial service but that the

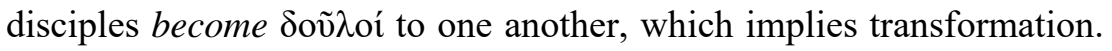
Authentic sacrificial service is inextricably linked to adopting a $\delta$ oṽ $\lambda$ os-identity and, conversely, the mimetic act of serving others

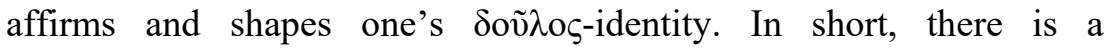
transformative relationship between mimetic behaviour and identity.

In other instances, too, we observe a correspondence between mimetic behaviour and identity. For example, Jesus' mimetic imperative in 13:34 is not simply to direct the disciples' behaviour but also to confirm their identity, as 13:35 clarifies: 'By this everyone will know that you are my disciples (identity), if you have love for one another (behaviour).' The mimetic unity among believers (identity), patterned on the unity of the Father and Son (17:21-22), is directly linked to testifying about Jesus (behaviour) (17:20). Looking at the Johannine letters, 1 John 3:7 shows that the habitual practice of doing what is right transforms the person into being right(eous) - in imitation of Jesus. In 1 John 3:16, the mimetic imperative that believers lay down their lives for each other just as Jesus did speaks to believers who have been transformed, having passed from death to life, as mentioned in $1 \mathrm{John} 3: 14$. At the same time, the regular practice of this sacrificial love-in-action (1 John 3:17-18) would naturally affirm and enhance their transformation (cf. 3 John 5-8). The mimetic transformation of believers into the likeness of Christ at the Parousia in 1 John 3:2 is unlikely to be an instant metamorphosis from one state into another and more likely to be a gradual transformation, resulting from a lifetime of imitating Jesus. In fact, the Johannine concept of mimesis manifests itself in two forms: 'performative' mimesis, referring to the imitation of 
actions or behaviour (e.g., in 13:15,34) and 'existential' mimesis, referring to states of existence or 'being' (e.g., in 17:11,21-22; 1 John 3:2). ${ }^{20}$ Hence, for John, mimesis shapes both identity and behaviour. We will now examine how mimesis may have worked among Johannine believers in the late first century.

\section{The Practice of Mimesis in Johannine Christianity}

Our study triggers at least two hermeneutical questions regarding the workings of mimesis (and resulting moral transformation) in Johannine Christianity. First, how could Johannine believers in the late first century, when John wrote his Gospel and Letters, imitate the departed Jesus whom they are unable to observe?21 Second, what were Johannine believers supposed to imitate about Jesus - his teachings, character, or entire lifestyle - and could they create new forms of mimesis, as John did in 1 John? In exploring these issues, I will propose two hermeneutical principles that can be used heuristically to approximate how transformative mimesis might have worked among Johannine Christians.

\subsection{The Mimesis of an 'Absent' Jesus'22}

By definition, mimesis is a sensory process, where the imitator observes what needs imitating. The Johannine concept of mimesis brings up an issue that seems at odds with this: how could Johannine Christians imitate Jesus when he had returned to the Father? Did mimesis mutate from first-hand observation to second-hand instruction on what to imitate? Not necessarily. David Capes has argued that there was a literary ethos in antiquity that promoted the idea of imitation. In Graeco-Roman and Jewish Hellenistic cultures, the virtuous lives of notable people were upheld as models for imitation, and while living models were preferred, the lives of great men from the past could be 'observed' (and imitated) through spoken and published accounts. ${ }^{23}$ Capes then shows that the Gospels as ancient biographies or ß1oí of

\footnotetext{
20 See also Bennema, Mimesis: 59-62.

21 Leung does not consider this crucial issue in her 'Ethics'.

22 Jesus' 'absence' refers to the spatial separation between Jesus in heaven and his followers on earth; yet, he is 'present' or accessible through the Spirit (see below).

23 Capes, 'Imitatio Christi': 3-10. See also Copan, Saint Paul: 40-71.
} 
Jesus provided early Christians with a script for imitation. ${ }^{24}$ John, too, knows of living and literary examples for imitation.

The Imitation of Living Examples. Interestingly, while Paul presents himself as an example for imitation (1 Cor. 4:16; 11:1; Phil. 3:17; 1 Thess. 1:6; 2 Thess. 3:7,9), John does not do so in his letters. ${ }^{25}$ In 3 John 11 (the only place in the Johannine writings where the lexeme

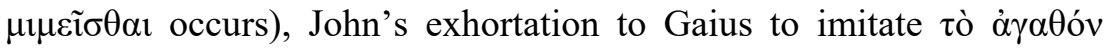
('that which is good') seems abstract and impersonal, but the latter half of the verse 'personalises' the imitation: o $\alpha \gamma \alpha \theta$ o $\pi$ or $\tilde{\omega} v$ ('the one who does good') probably indicates the one who imitates tò à $\gamma \alpha \theta$ óv ('that which is good'). Besides, considering the immediate context (3 John 912), 'that which is evil' and 'that which is good' refers to the conduct of Diotrephes and Demetrius respectively. ${ }^{26}$ Hence, John points Gaius to the living example of Demetrius for imitation. We could extend John's exhortation to believers in general, instructing them to imitate what is good in the lives of other Christians. ${ }^{27}$

The Imitation of Literary Examples. John has recorded the life and teachings of Jesus as he remembered and understood them in his Gospel and Letters, so his audience can reconstruct this 'remembered' Jesus from the Johannine text. ${ }^{28}$ In other words, Johannine Christians can observe, study, and imitate the 'reconstructed' Jesus from the text. The fact that 1 John introduces several new instances of the believer-

24 Capes, 'Imitatio Christi': 13-19. Richard Burridge made the compelling case for viewing the Gospels as ancient biographies (What Are the Gospels? A Comparison with Graeco-Roman Biography [2nd ed.; Grand Rapids: Eerdmans, 2004; orig. 1992]) and later explored the mimetic aspect of the Gospels as Broi (Imitating Jesus: An Inclusive Approach to New Testament Ethics [Grand Rapids: Eerdmans, 2007]).

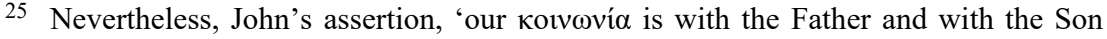
Jesus Christ' (1 John 1:3) implies that he lived out a Christ-like life before his community (Jeffrey E. Brickle, 'Transacting Virtue within a Disrupted Community: The Negotiation of Ethics in the First Epistle of John', in Rethinking the Ethics of John: 346).

26 De Boer, Imitation: 85.

27 Paul uses the term $\tau$ í $\pi$ os ('example, model [for imitation]') regarding people who could model the Christian life to his audience in his absence: e.g. Timothy (1 Tim. 4:12), Titus (Titus 2:7,) or Christ-like believers (Phil. 3:17b).

28 The Johannine writings assert they are based on eyewitness testimony (see the 'we' in $1: 14 ; 21: 24 ; 1$ John 1:1-3; cf. 19:35). In 1 John 1:1-3, John explains that he is communicating the divine realities he and others have observed first hand (he refers to the senses of hearing, sight, and touch) to an audience that has not had this experience but can 'know' (and experience) these realities through his written testimony. Before John had produced his Gospel, the oral tradition about Jesus would have been the means for a 'visualised' Jesus. 
Jesus mimesis (1 John 2:6; 3:2,3,7,16) shows that John expects his readers to be able to imitate Jesus. While John knows of the Spirit mediating the presence of Jesus (and the Father) to believers (14:1617,$23 ; 1$ John $3: 24 ; 4: 13$ ), he can hardly be suggesting a scenario where the Spirit visibly shows what believers must imitate. Instead, John preserves Jesus' personal example in his writings, and draws attention to Spirit-enabled remembrance and interpretation (14:26; 16:12-15). The Spirit's role is to enable the remembrance of Jesus and guide Johannine believers in 'visualising' a reconstructed Jesus from the text to aid their imitation of him. The Johannine text thus functions as the basis for mimesis in that readers can 'observe' the example of Jesus in the text and construct a literary or 'symbolic' Jesus to imitate.

In addition to Jesus, other characters in the Johannine narrative can also function as models for imitation. The Johannine characters are potential moral agents in that they can be role models for moral reasoning and behaviour, thus effecting moral transformation. ${ }^{29}$ The character of Thomas in John 20 has a special role in that he conceptually facilitates the transition from living to literary examples. Thomas's experience in 20:24-29 represents the struggle of later generations of believers who have not witnessed the resurrection of Jesus and must depend on the testimony of others to believe. Yet, such believers are not at a disadvantage; they can have a tangible experience of the risen Jesus through oral and written testimony. ${ }^{30}$

In sum, Jesus' 'absence' was not an insurmountable problem because mimesis could be conveyed in antiquity by means of living or literary examples. While John occasionally uses living examples (exemplary Christians) to encourage the imitatio Christi among the believing community, the primary basis for mimesis is his written eyewitness testimony about Jesus. Johannine Christians can reconstruct the Jesus that John personally observed, remembered, and preserved in his writings. John's portrayal of Thomas shows that we need not distinguish between the historical disciples and later generations of believers. Whatever the original disciples had observed and

29 For several case studies, see Bennema, 'Virtue Ethics': 277-78; idem, 'Virtue Ethics in the Gospel of John: The Johannine Characters as Moral Agents' in Rediscovering John: Essays on the Fourth Gospel in Honor of Frédéric Manns, L. Daniel Chrupcała, ed. (Milan: Edizioni Terra Santa, 2013): 167-81, here 174-79.

30 See Cornelis Bennema, Encountering Jesus: Character Studies in the Gospel of John (2nd ed.; Minneapolis: Fortress, 2014): 293-94. 
remembered about Jesus' life and teaching is accessible to later believers as they hear or read the Johannine accounts, aided by the Spirit who interprets Jesus' teaching.

\subsection{The Content or Focus of Mimesis}

Considering the Johannine text is a basis for mimesis, what aspects of Jesus should Johannine Christians imitate? Should they imitate specific actions, the intentions behind those actions (resulting in a general mindset of moral discernment), or Jesus' entire lifestyle? Andrew Kille suggests that the issue is not what people should imitate from the accounts of Jesus' life but what values they can learn from Jesus' way of living. ${ }^{31}$ Similarly, Phillipe Nicolet argues that the imitation of Christ (through the imitation of Paul) does not imply that Christ is a model to be imitated but refers to living one's life 'in Christ'. ${ }^{32}$ While these scholars are being careful not to depict mimesis as aping or mindless replication of Jesus' actions, and recognise the need to discern the underlying intentions and attitudes, I contend that we should not dichotomise Jesus' specific actions and his intentions. I have suggested that the believers' mimetic actions should fall in the conceptual mimetic domain of the original act (Section 3.2). Burridge adopts a broad stance on imitating Jesus: 'People have to emulate his [Jesus'] open pastoral acceptance of others, especially those whom some may consider to be "sinners". ${ }^{33}$ In my view, however, such a concept of imitation is too broad and insufficiently controlled by the Johannine text. I propose a hermeneutical control in the mimetic process where we 'observe' and imitate those aspects of Jesus' life that are indicated by the Johannine text.

While it is valid to imitate Jesus' specific actions, general mindset, or entire lifestyle, I suggest we need to hold these together. The footwashing, for example, provides a concrete example of mimesis; yet, the mimetic act should also embody the intention and attitude

31 D. Andrew Kille, 'Imitating Christ: Jesus as Model in Cognitive Learning Theory' in Text and Community: Essays in Memory of Bruce M. Metzger, J. Harold Ellens, ed. (Sheffield: Sheffield Phoenix Press, 2007): 251-63.

32 Phillipe Nicolet, 'Le Concept d'imitation de l'apôtre dans la correspondance paulinienne' in Paul, une théologie en construction, Andreas Dettwiler, Jean-Daniel Kaestli, and Daniel Marguerat, ed., (Le Monde de la Bible 51; Geneva: Labor et Fides, 2004): 393-415, here 412-13.

33 Burridge, Imitating Jesus: 77. He then sees this pattern in John's Gospel (Imitating Jesus: $343-45)$. 
underlying the original example. John's exhortation that believers conduct themselves like Jesus (1 John 2:6) contains no explicit instructions precisely because this will require them to reflect on Jesus' entire life and contemplate how they can imitate him. ${ }^{34}$ While people cannot imitate every aspect of Jesus' life, such as dying on the cross for the sake of humanity, John nevertheless takes Jesus' saying in 15:13 to mean that Jesus' sacrificial love becomes an example for imitation (1 John 3:16; cf. the remark in 21:18-19 that Peter will imitate Jesus in death). What believers should embody are Jesus' teachings or lived-out ethos of God's world, preserved in the Johannine text.

We noted that John did not limit himself to the explicit mimetic examples that Jesus had set during his ministry; rather, he extrapolated new forms of mimesis from the teachings and examples of Jesus. This suggests that Johannine Christians (and later believers) can also extend an action or saying of Jesus into a mimetic imperative - 'Just as Jesus did, so also should we.' Indeed, when we glance further along the Johannine tradition, into the time of the Apostolic Fathers, we find examples of mimesis that are arguably rooted in Jesus' teaching. In the second century, the idea of martyrdom as the ideal imitatio Christi became prevalent (e.g. Ign. Rom. 6:1-3; Mart. Pol. 17:3; 19:1). ${ }^{35}$ If Ignatius and Polycarp were familiar with the Johannine tradition, ${ }^{36}$ the imitation of Jesus' death could be traced back via John's newly-created mimetic imperative in 1 John 3:16 to Jesus' saying in John 15:13.

\subsection{Applied Hermeneutics}

Based on the previous discussion, I suggest two hermeneutical principles. First, the Johannine text is the basis and boundary for mimesis. Jesus' instruction to abide in his words (15:7; cf. 14:23; $15: 10)$ requires us not only to contemplate, study, and observe them but

\footnotetext{
34 Although we noted in Section 3.2 that John portrays this Christ-like behaviour as one characterised by light, truth, and love, this must be unpacked through moral reasoning.

35 See de Boer, Imitation: 15; Paul Middleton, Radical Martyrdom and Cosmic Conflict in Early Christianity (LNTS 307; London: Bloomsbury T\&T Clark, 2006): 82-84 (he also mentions several parallels between the deaths of Jesus and Polycarp).

36 Kenneth Berding, 'John or Paul? Who Was Polycarp's Mentor?', TynB 58 (2007): 135-43; Helmut Löhr, 'The Epistles of Ignatius of Antioch' in The Apostolic Fathers, Wilhelm Pratscher, ed. (Waco: Baylor University Press, 2010): 91-115, here 101-102; Murray J. Smith, 'The Gospels in Early Christian Literature' in The Content and Setting of the Gospel Tradition, Mark Harding and Alanna Nobbs, ed. (Grand Rapids: Eerdmans, 2010): 204.
} 
also to remain within their boundaries (see 2 John 9). At first glance, John's new forms of mimesis in 1 John seem to contravene the principle just stated, but a closer look shows that these new forms of mimesis are extrapolated from and remain within the boundaries of Jesus' teaching (see Section 3.2). Second, the assistance of the Spirit as an interpretative agent is another hermeneutical principle. The Johannine writings depict the Spirit as having an interpretative role $(14: 26 ; 16: 12-15 ; 1$ John 2:20,27; 2 John 9), present to aid believers in reconstructing Jesus from the text. Hence, the two interrelated hermeneutical devices available to believers for imitating Jesus are the text and the Spirit. Jesus (and his exemplary behaviour) is preserved in the text and readers must, guided by the Spirit, reconstruct 'observable behaviour' from the text. The Spirit aids believers in (i) reconstructing Jesus from the text; (ii) interpreting Jesus' example and enabling mimesis; (iii) inferring new forms of mimesis from Jesus' teaching. This Spirit-led moral reasoning and mimetic behaviour effects moral transformation. ${ }^{37}$

Glen Lund is one of few scholars who consider how Jesus may have functioned as an ethical model within the believing community:

For all their nobility and wide-ranging application the ethical principles of the fourth gospel certainly lack specificity. Other than in the footwashing ceremony, none of Jesus' commands are fleshed out by detailed instructions indicating how they might be practically applied. Each command ultimately refers to the example of Jesus as the basis of their application which is a dynamic tradition that is neither fixed nor systematic. The ultimate test for Johannine moral acceptability could perhaps be described as intimate connection to Jesus/God through belief and faithfulness to his testimony within the Spirit-guided community.

In practice, the moral conduct in the Johannine community would not have been governed by the fourth gospel but would have been fleshed out by their corporate memory of Jesus and supplemented by remembered, internalised values from the Torah ... This would mean

37 In a recent study based on cognitive psychology, Joshua Cockayne recognises the transformative aspect of mimesis but argues that this requires an experience of Christ in the present, through the indwelling Spirit, in which the imitator can perceive Christ's intentions and behaviour ('The Imitation Game: Becoming Imitators of Christ', RS 53 [2017]: 3-24). My concern is that mimesis rooted in the contemporary experience of Christ could lead to uncontrolled, subjective interpretations, whereas I suggest that the imitation of Jesus should be text centred, i.e., controlled by Jesus' examples and behaviour preserved in the text. Hermeneutically, the 'contemporary' Jesus of personal experience should correspond to the 'reconstructed' Jesus from the text. 
that Johannine ethical practice would be based on relational unity and communal values, not written texts and fixed laws. ${ }^{38}$

There is much to commend in Lund's view of a Torah-based, Spiritguided community ethics, but it does not, in my view, go to the heart of Johannine ethics. Rather, the personal example of Jesus, preserved in the text of John's Gospel and extrapolated in his Letters, is central to Johannine ethics. ${ }^{39}$

\section{Conclusion}

When people enter God's world, their participation in the divine commodities such as life, light, love, and truth effects moral transformation. Believers will be transformed to the extent that they practise moral reasoning and behave in accordance to the ethos of God's world. The concept of mimesis turns out to be instrumental in this process of moral transformation. We argued that mimesis was not limited to the original disciples who were able to observe Jesus. Later generations of believers could 'observe' Jesus in the Gospel's eyewitness account and in John's Letters, where he crafts further examples of mimesis. Indeed, the possible reception history of the Johannine tradition in the second century shows that martyrdom as the ideal imitatio Christi can be traced back via John (in 1 John) to Jesus (in John's Gospel). The main hermeneutical aids to guide the believer's imitation of Jesus are the text and the Spirit, although mature believers could also function as living examples for imitation.

38 Glen Lund, 'The Joys and Dangers of Ethics in John's Gospel' in Rethinking the Ethics of John: 278, 280. For the idea of intimate relationships enabling ethical living, see Volker Rabens' essay in the same volume ('Johannine Perspectives on Ethical Enabling in the Context of Stoic and Philonic Ethics': 114-39).

39 For a detailed discussion, see Bennema, Mimesis: 165-68. Even though Lund mentions the idea of imitating Jesus, he does not make it sufficiently central to Johannine ethics ('Joys': 277, 283, 287-88). 